\title{
Pharmacologic Treatments for Acute Respiratory Distress Syndrome
}

\author{
Nida Qadir, MD*, Steven Y. Chang, MD, PhD
}

\section{KEYWORDS}

- ARDS • Neuromuscular blockade • Corticosteroids • Pulmonary vasodilators

\section{KEY POINTS}

- The management of acute respiratory distress syndrome is primarily supportive.

- No pharmacologic intervention has yet demonstrated a clear mortality benefit in acute respiratory distress syndrome.

- Improvement in surrogate end points does not necessarily translate into improved survival.

- There is a growing body of evidence suggesting that corticosteroids may improve outcomes in certain subgroups of patients with acute respiratory distress syndrome.

- Further research is needed to assess the impact of investigational therapies such as vitamin C, mesenchymal stromal cells, and granulocyte-macrophage colony stimulating factor.

\section{INTRODUCTION}

Over 50 years have passed since the acute respiratory distress syndrome (ARDS) was first described. ${ }^{1}$ Despite the passage of more than one-half of a century, almost all of ARDS care continues to be supportive in nature, and mortality remains high at $34 \%$ to $45 \% .^{2}$ As our understanding of ARDS pathophysiology has improved, a number of pharmacologic interventions have been tested, including those targeting ventilatorassociated lung injury (VALI), dead space ventilation, inflammation, alveolar epithelial and capillary endothelial injury, and dysfunctional fluid clearance. Although no medications have yet demonstrated a clear mortality benefit in ARDS, a number of therapies are currently being evaluated in clinical trials (Table 1). In this article, we review selected pharmacologic treatments for ARDS.

David Geffen School of Medicine at UCLA, 10833 Le Conte Avenue, Room 43-229 CHS, Los Angeles, CA 90095, USA

* Corresponding author.

E-mail address: nqadir@mednet.ucla.edu 


\section{COMMONLY USED THERAPIES}

Widely available therapies, and those studied in large clinical trials, include neuromuscular blockade, corticosteroids, and inhaled pulmonary vasodilators. These therapies are frequently used in the clinical setting, despite a lack of strong evidence favoring their use in ARDS. We examine each here, in the context of underlying pathophysiology.

\section{Neuromuscular Blockade}

Much of ARDS care is supportive in nature, with lung protective mechanical ventilation as its mainstay. VALI is a well-known occurrence, and approaches to mechanical ventilation are aimed at minimizing it and avoiding its complications. The use of neuromuscular blockade is rationalized as a measure that may decrease the occurrence of VALI, which can be caused by both overdistension (volutrauma, and to a lesser extent, barotrauma) and repeated opening and closing of underrecruited alveoli (atelectrauma). Patients with heterogenous consolidation (Fig. 1), often seen in ARDS, are at particularly high risk for both.

The impact of large tidal volumes on lung injury and the protective effect of positive end-expiratory pressure (PEEP) are well-illustrated in a murine model. Dreyfuss and colleagues $^{3}$ examined the effects of 5 different ventilator strategies in rats: low pressure-low tidal volume, high pressure-high tidal volume, high pressure-high volume with PEEP, high pressure-low volume (achieved by banding the chest wall), and low pressure-high volume. The rats ventilated with high volumes all had evidence of pulmonary edema.

However, edema was markedly decreased by PEEP. The low-volume groups had an essentially normal lung structure, including the high pressure-low volume group. Intuitively, one would predict that high airway pressures would play a significant role in VALI, but these findings demonstrated that it is actually the transalveolar gradient (intra-alveolar minus pleural pressure) that plays a more substantial role. Additionally, the protective effect of PEEP seen in this model may have been mediated by a decrease in atelectrauma.

Dysfunctional surfactant and gravitational forces resulting in the nonuniform distribution of edema can result in a difficult to recruit lung, regional overdistension, and thus atelectrauma. The application of PEEP can help to mitigate this factor by stenting

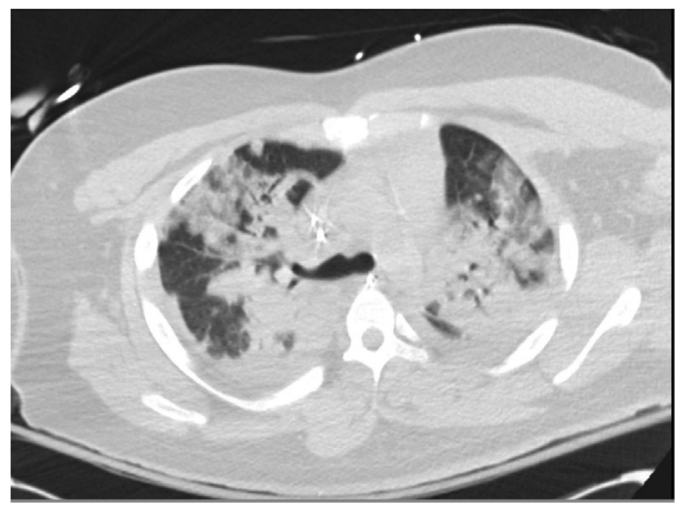

Fig. 1. Heterogenous consolidation in ARDS seen on a computed tomography scan. 
open alveoli and preventing the shear forces associated with repeated alveolar opening and collapse. ${ }^{3}$

Large changes in volume can also lead to a disruption of the alveolar epithelial and capillary endothelial interface, with the resultant release of inflammatory mediators, worsening pulmonary edema, further compromise in gas exchange, and, in turn, a perpetual loop of worsening lung injury. ${ }^{4}$ Although lung protective ventilator strategies involve low tidal volume ventilation and application of relatively high levels of PEEP, ${ }^{5,6}$ current sedation strategies emphasizing daily awakenings and/or light sedation, ${ }^{7}$ leading to a fair amount of patient-ventilator interaction. Patients with a high metabolic demand and respiratory drive often attempt to generate higher tidal volumes, which may result in ventilator asynchronies, such as double triggering and even active exhalation, leading to the collapse of alveoli. Repeated collapse and hyperinflation can then in turn lead to worsening lung injury. As such, it may follow that, if a patient is breathing completely passively on the ventilator, there may be a decrease in VALI and an increased potential for healing. Neuromuscular blockade has been used for decades with this rationale in mind.

Although a number of neuromuscular blocking agents have been used for the management of ARDS, the use of older nondepolarizing neuromuscular blocking agents (pancuronium, vecuronium, or atracurium), especially in conjunction with systemic corticosteroids, in critically ill, mechanically ventilated patients has become increasingly limited owing to concerns for critical illness weakness. ${ }^{8}$ Hepatic or renal failure, common in these patients, seems to increase the likelihood of persistent weakness substantially. Cisatracurium is a newer nondepolarizing agent that is metabolized via Hoffman degradation to metabolites without neuromuscular blocking activity. It is also associated with a decrease in both pulmonary and systemic inflammatory cytokines, ${ }^{9}$ which may be a result not only of minimizing VALI, but also a direct effect of the cisatracurium itself. ${ }^{10}$ It is not associated with intensive care unit (ICU)-acquired weakness ${ }^{11}$ and, in comparison with vecuronium, cisatracurium is associated with fewer ICU and ventilator days, ${ }^{12}$ suggesting that it may be a preferable neuromuscular blocking agent for patients with ARDS.

The usefulness of cisatracurium for the management of ARDS has been assessed in multiple clinical trials (Table 2). In the ACURASYS trial, Papazian and colleagues ${ }^{13}$ randomized 340 patients with moderate-to-severe ARDS (P/F $\leq 150)$ to either cisatracurium, or placebo (with deep sedation) for 48 hours in a blinded fashion. Although the crude 90-day mortality was not different, after adjustment for baseline oxygenation, Simplified Acute Physiology Score II, and plateau pressure, mortality did seem to be decrease with a hazard ratio of 0.68 (95\% confidence interval, $0.48-0.98 ; P=.04)$. Additionally, there was an increase in the number of ventilator free days both at 28 and 90 days. ${ }^{13}$ This trial was criticized because it was underpowered, a mortality benefit was only seen after statistical adjustment, and the control arm consisted of deep sedation to maintain blinding (in contrast with modern practices of daily awakenings or light sedation). Additionally, the assessment of critical care weakness, although performed, was inadequate, and thus remained mostly unresolved. Despite these issues, a prospective, multicenter epidemiologic study showed that $22 \%$ of all patients with ARDS and $38 \%$ of patients with severe ARDS received neuromuscular blockade. ${ }^{2}$ Additionally, a survey of academic intensivists showed that $97 \%$ of respondents used paralytics in managing patients with ARDS, and that $40 \%$ of intensivists use neuromuscular blockade in more than one-half of their patients. ${ }^{14}$ In light of the limitations of ACURASYS, the usefulness of cisatracurium for the management of ARDS was recently reexamined in the Reevaluation of Systemic Early Neuromuscular Blockade (ROSE), a multicenter, randomized, controlled trial comparing early 


\begin{tabular}{|c|c|c|}
\hline Therapy & Mechanism of Action & Findings to Date \\
\hline $\begin{array}{l}\text { Neuromuscular } \\
\text { blockade }^{11,13}\end{array}$ & $\begin{array}{l}\text { Possible } \downarrow \text { VALI occurrence } \\
\text { via } \downarrow \text { patient-ventilator } \\
\text { interaction }\end{array}$ & $\begin{array}{l}\text { No impact on mortality in } \\
\text { moderate-to-severe } \\
\text { ARDS } \\
\text { No impact on incidence of } \\
\text { ICU-acquired weakness } \\
\text { (specifically with short- } \\
\text { term use of } \\
\text { cisatracurium) } \\
\end{array}$ \\
\hline Corticosteroids ${ }^{19-26}$ & $\begin{array}{l}\downarrow \text { Synthesis of } \\
\text { proinflammatory } \\
\text { mediators }\end{array}$ & $\begin{array}{c}\text { Possible } \downarrow \text { mortality in early } \\
\text { ARDS ( }<14 \mathrm{~d} \text { since onset) } \\
\text { Possible } \uparrow \text { mortality in late } \\
\text { ARDS ( }>14 \mathrm{~d} \text { since onset) } \\
\uparrow \text { Ventilator-free days } \\
\end{array}$ \\
\hline $\begin{array}{l}\text { Inhaled pulmonary } \\
\text { vasodilators }\end{array}$ & $\begin{array}{l}\downarrow \text { Ventilation-perfusion } \\
\text { mismatch }\end{array}$ & $\begin{array}{l}\uparrow \text { Oxygenation (short term) } \\
\text { No known impact on } \\
\text { mortality } \\
\text { Possible } \uparrow \text { risk of renal } \\
\text { failure (iNO) }\end{array}$ \\
\hline Vitamin $C^{55-61}$ & $\begin{array}{l}\downarrow \text { Expression of } \\
\text { proinflammatory } \\
\text { mediators } \\
\downarrow \text { Microvascular thrombosis } \\
\text { Enhancement of epithelial } \\
\text { barrier function } \\
\end{array}$ & $\begin{array}{l}\text { Possible } \downarrow \text { mortality, ICU } \\
\text { and hospital days in } \\
\text { patients with } \\
\text { ARDS + sepsis } \\
\text { (exploratory finding) }\end{array}$ \\
\hline Beta-agonists $^{63-67}$ & $\begin{array}{l}\uparrow \text { Alveolar fluid clearance } \\
\downarrow \text { Lung vascular } \\
\text { permeability }\end{array}$ & $\begin{array}{l}\uparrow \text { Mortality and ICU days } \\
\text { Clinical trial assessing role } \\
\text { of inhaled beta agonists } \\
\text { for prevention of acute } \\
\text { respiratory failure } \\
\text { ongoing (NCT04193878) }\end{array}$ \\
\hline Statins ${ }^{68-73}$ & $\begin{array}{l}\downarrow \text { Synthesis of } \\
\text { proinflammatory } \\
\text { mediators }\end{array}$ & $\begin{array}{l}\text { No impact on mortality or } \\
\text { ventilator-free days } \\
\text { Possible benefit in } \\
\text { hyperinflammatory } \\
\text { subphenotype } \\
\text { (exploratory finding) } \\
\end{array}$ \\
\hline $\begin{array}{l}\text { Mesenchymal Stromal } \\
\text { Cells }^{74-77}\end{array}$ & $\begin{array}{l}\text { Enhanced epithelial/ } \\
\text { endothelial repair } \\
\text { Improved phagocytosis } \\
\uparrow \text { Alveolar fluid clearance }\end{array}$ & $\begin{array}{l}\text { Safety established in phase } \\
\text { I and IIA studies } \\
\text { Multiple clinical trials } \\
\text { ongoing } \\
\text { (NCT02444455, } \\
\text { NCT03608592, } \\
\text { NCT03042143, } \\
\text { NCT04367077) } \\
\end{array}$ \\
\hline GM-CSF $24,78-80$ & $\begin{array}{l}\downarrow \text { Oxidative epithelial cell } \\
\text { injury Enhanced } \\
\text { phagocyte function }\end{array}$ & $\begin{array}{l}\text { Possible } \downarrow \text { hypoxia and } \\
\text { severity of illness } \\
\text { (exploratory finding) } \\
\text { Clinical trial of inhaled GM- } \\
\text { CSF ongoing } \\
\text { (NCT02595060) }\end{array}$ \\
\hline
\end{tabular}




\begin{tabular}{|c|c|c|}
\hline $\begin{array}{l}\text { Table } 1 \\
\text { (continued) }\end{array}$ & & \\
\hline Therapy & Mechanism of Action & Findings to Date \\
\hline Surfactant $^{87,88}$ & $\begin{array}{l}\text { Replacement of deficient or } \\
\text { dysfunctional } \\
\text { endogenous surfactant } \\
\downarrow \text { Alveolar surface tension } \\
\downarrow \text { Hydrostatic force driving } \\
\text { pulmonary edema } \\
\end{array}$ & $\begin{array}{l}\text { No impact on mortality } \\
\text { No impact on oxygenation }\end{array}$ \\
\hline Interferon $\beta$-1 $\mathrm{a}^{89}$ & $\begin{array}{l}\text { Prevention of vascular } \\
\text { leakage } \\
\text { Inhibition of leukocyte } \\
\text { recruitment }\end{array}$ & $\begin{array}{l}\text { No impact on mortality } \\
\text { No impact on ventilator- } \\
\text { free days }\end{array}$ \\
\hline
\end{tabular}

neuromuscular blockade to light sedation in ARDS in 1006 patients. One of the biggest differences between the 2 trials were the control arms - a strategy of daily awakenings or light sedation - is known to result in improved outcomes when compared with deep sedation. ${ }^{7,15}$ In the ROSE trial, no difference was seen between the 2 groups in hospital mortality, ventilator-free days, ICU-free days, or hospital-free days. The cisatracurium group was less mobile while in the hospital and did have more adverse

Table 2
Comparison of findings from 2 landmark studies on the use of cisatracurium in ARDS

\begin{tabular}{cc} 
ACURASYS $^{13}$ & ROSE $^{11}$ \\
\hline $\begin{array}{c}\text { Multicenter, randomized } \\
\text { trial of } 340 \text { patients }\end{array}$ & $\begin{array}{c}\text { Multicenter, randomized } \\
\text { trial of } 1006 \text { patients }\end{array}$ \\
\hline $\begin{array}{c}\text { Double-blind-control } \\
\text { group required deep sedation }\end{array}$ & $\begin{array}{c}\text { Unblinded-control group } \\
\text { sedation strategy was either } \\
\text { to target RASS of -1 to 0, or } \\
\text { to perform daily awakenings }\end{array}$
\end{tabular}

Importance

ACURASYS was

underpowered

to detect a mortality

difference without

statistical adjustment

Daily awakenings and

light sedation have

been shown to improve

outcomes compared

with deep sedation, so

there is concern that

the control arm in

ACURASYS fared

more poorly than

they would have

with modern

sedation strategies

\begin{tabular}{|c|c|c|}
\hline $\begin{array}{l}\text { Patients enrolled with } \\
\text { P/F of }<150 \text { on a PEEP } \\
\text { of } \geq 5 \mathrm{~cm} \mathrm{H} \mathrm{H}_{2} \mathrm{O} \\
\end{array}$ & $\begin{array}{l}\text { Patients enrolled with P/F of } \\
<150 \text { on a PEEP of } \geq 8 \mathrm{~cm} \mathrm{H}_{2} \mathrm{O}\end{array}$ & $\begin{array}{l}\text { ROSE may have initially } \\
\text { enrolled a more } \\
\text { hypoxic cohort }\end{array}$ \\
\hline $\begin{array}{l}\text { Enrollment allowed up to } \\
48 \mathrm{~h} \text { after meeting criteria. } \\
\text { Median time to enrollment was } \\
16 \text { hours [interquartile range, } \\
6-29 \text { hours] } \\
\end{array}$ & $\begin{array}{l}\text { Enrollment allowed up to } \\
48 \mathrm{~h} \text { after meeting criteria. } \\
\text { Median time to enrollment } \\
\text { was } 8 \text { hours [interquartile } \\
\text { range, } 4-16 \text { hours] }\end{array}$ & $\begin{array}{l}\text { ROSE may have enrolled } \\
\text { patients who may } \\
\text { not have survived } \\
\text { to be enrolled in } \\
\text { ACURASYS } \\
\end{array}$ \\
\hline $\begin{array}{l}\text { Ventilatory strategy was } \\
\text { low-tidal volume coupled } \\
\text { with a conventional } \\
\text { PEEP table }\end{array}$ & $\begin{array}{l}\text { Ventilatory strategy was } \\
\text { low tidal volume coupled } \\
\text { with a moderately high } \\
\text { PEEP table }\end{array}$ & Unclear \\
\hline
\end{tabular}


cardiovascular events. Importantly, the ROSE trial, in more robust fashion than in ACURASYS, also confirmed that cisatracurium was not associated with ICUacquired weakness. Although longer term outcomes require further research, the use of neuromuscular blockade was not associated with differences in survival, disability, cognitive function or psychiatric symptoms in the ROSE study. Despite the results of these trials, neuromuscular blockade may have therapeutic value in carefully selected patients with severe ARDS, substantial ventilator asynchrony, and

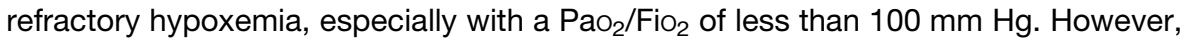
its routine use cannot be recommended.

\section{Corticosteroids}

The pathologic features of ARDS include a marked acute inflammatory response precipitated by alveolar epithelial and capillary endothelial injury. ${ }^{16}$ Processes that trigger ARDS, such as sepsis and pancreatitis, are frequently inflammatory themselves, as is VALI, often a consequence of supportive care for ARDS with mechanical ventilation.

Corticosteroids are anti-inflammatory and immunosuppressive. They act by binding to cell-surface receptors, and then translocate to the cell nucleus, where they inhibit the synthesis of proinflammatory mediators, such as cytokines, chemokines, inflammatory enzymes, receptors, and proteins. ${ }^{17}$ Corticosteroids are widely administered to patients with ARDS, both for the management of ARDS or for concurrent conditions such as septic shock or pneumonia. In a large US cohort, $44 \%$ of patients with moderate-to-severe ARDS received corticosteroids. ${ }^{18}$ However, the benefit of steroids in ARDS remains unclear, despite a number of studies assessing their use in ARDS and ARDS-related conditions (Table 3).

There has been substantial heterogeneity in steroid dosing, timing, and duration in clinical trials studying steroids in ARDS, and results have been mixed. In 1 trial comparing the early administration of very high-dose methylprednisolone $(120 \mathrm{mg} /$ kg over 24 hours in divided doses) with placebo in 99 patients with ARDS, no

\begin{tabular}{|c|c|}
\hline Patient Population & Findings to Date \\
\hline ARDS (all causes) ${ }^{19-26}$ & $\begin{array}{l}\text { Possible } \downarrow \text { mortality in early ARDS ( }<14 \mathrm{~d} \text { since } \\
\text { onset) } \\
\text { Possible } \uparrow \text { mortality in late ARDS ( }>14 \mathrm{~d} \text { since } \\
\text { onset) } \\
\uparrow \text { Ventilator-free days }\end{array}$ \\
\hline Community-acquired pneumonia ${ }^{27-33}$ & $\begin{array}{l}\downarrow \text { Treatment failure } \\
\downarrow \text { Hospital length of stay } \\
\downarrow \text { Risk of ARDS }\end{array}$ \\
\hline Influenza 34 & $\begin{array}{l}\text { Possible } \uparrow \text { mortality } \\
\text { Possible } \uparrow \text { hospital-acquired infection } \\
\text { Delayed viral clearance }\end{array}$ \\
\hline Middle Eastern respiratory syndrome ${ }^{36}$ & $\begin{array}{l}\text { No impact on mortality } \\
\text { Delayed viral clearance }\end{array}$ \\
\hline Severe acute respiratory syndome $\mathrm{s}^{35}$ & $\begin{array}{l}\text { Unclear impact on mortality } \\
\text { Delayed viral clearance }\end{array}$ \\
\hline COVID-19 $37-40$ & $\begin{array}{l}\downarrow \text { Mortality } \\
\uparrow \text { Ventilator-free days }\end{array}$ \\
\hline
\end{tabular}


difference was found in the 45-day mortality rate, or in the reversal of ARDS. ${ }^{19}$ However, a small subsequent placebo-controlled trial in 24 patients assessing a prolonged course of lower dose methylprednisolone $(2 \mathrm{mg} / \mathrm{kg} / \mathrm{d}$ with tapering over a maximum of 32 days) in unresolving ARDS ( $\geq 7$ days of mechanical ventilation) reported that steroids were associated with improvements in both physiologic parameters and mortality (ICU and hospital), although there was substantial cross-over in this trial. ${ }^{20}$ Similar findings were reported in a larger multicenter, randomized, placebo-controlled trial using even more modest doses of methylprednisolone $(1 \mathrm{mg} / \mathrm{kg} / \mathrm{d}$ with taper, for $\leq 28$ days) for early ARDS (within 72 hours of onset), which demonstrated decreased duration of mechanical ventilatory support, ICU length of stay, and mortality $(20.6 \%$ vs $42.9 \% ; P=.03$ ) in patients receiving steroids. ${ }^{21}$ Unfortunately, these mortality benefits were not replicated in the Late Steroids Rescue Study (LaSRS) performed by the ARDS Clinical Trials Network. ${ }^{22}$ Despite an increase in the number of ventilator-free days and shock-free days in patients with ARDS for more than7 days, the overall mortality rate was not decreased, and there was a concerning increase in 60- and 180-day mortality rates in the subset of patients given steroids more than 2 weeks after onset of ARDS. Some meta-analyses have suggested that steroids may reduce mortality and increase ventilator-free days in ARDS, particularly in patients treated within 14 days of onset, ${ }^{23-25}$ indicating that the role of steroids should be further evaluated in early ARDS. Very recently, an unblinded, randomized, controlled trial of 277 patients comparing a 10-day regimen of dexamethasone with placebo in early ARDS (within 30 hours of meeting the Berlin Criteria) was conducted, demonstrating a significant decrease in the primary end point of ventilator-free days at 28 days (12.3 \pm 9.9 vs $7.5 \pm 9.0$ days; $P<.0001)$, and a secondary end point of all-cause mortality at 60 days $(21 \%$ vs $36 \%$; $P<.0047) .{ }^{26}$ However, some criticisms of this trial included slow enrollment occurring over 5 years, an inability to complete the planned enrollment, and the exclusion of a large number of patients.

Consistent with the hypothesis that steroids may be beneficial in lung injury, the role of steroids has also been tested in community-acquired pneumonia. Multiple clinical trials have found that steroids improve outcomes in severe community-acquired pneumonia, ${ }^{27-29}$ primarily with regard to the resolution of pneumonia, including two multicenter, randomized, double-blind, placebo-controlled trials. The first trial included 304 patients with community-acquired pneumonia and found that dexamethasone decreased the hospital length of stay by 1 day compared with placebo. ${ }^{30} \mathrm{~A}$ subsequent trial of 120 patients with community-acquired pneumonia and high inflammatory response (C-reactive protein of $>150 \mathrm{mg} / \mathrm{L}$ at admission), found that the use of methylprednisolone decreased treatment failure. ${ }^{31}$ These findings have been redemonstrated in recent meta-analyses. ${ }^{32,33}$ Similarly, the use of corticosteroids in viral pneumonias has also been evaluated, but with mixed results. Although prior studies evaluating the use of steroids in viral pneumonias have been associated with delayed viral clearance and possible harm, ${ }^{34-36}$ there has been marked heterogeneity in these trials. A retrospective review of 774 patients with COVID-19, $90 \%$ of whom were receiving oxygen by simple nasal cannula, found that corticosteroid therapy was associated with harm, particularly in those who received high-dose steroids (>200 mg of hydrocortisone or the equivalent) and who received them in the first 3 days of hospitalization. ${ }^{37}$ Other clinical trials, however, have found that corticosteroids improved outcomes in patients with COVID-19 with acute hypoxemic respiratory failure. ${ }^{38-40}$ The RECOVERY group randomized 2104 patients with COVID-19 to dexamethasone ( $6 \mathrm{mg} / \mathrm{d}$ for $\leq 10$ days), and 4321 to usual care. They showed that the use of dexamethasone in these patients resulted in a lower 28-day mortality in those requiring invasive mechanical ventilation ( $29 \%$ vs $41 \%)$, as well as in patients receiving 
supplemental oxygen without invasive mechanical ventilation ( $23 \%$ vs $26 \%) .{ }^{40} \mathrm{~Pa}-$ tients with COVID-19 ARDS were the focus of the multicenter CoDEX trial, which randomized 299 patients with moderate-to-severe ARDS to high-dose dexamethasone (20 mg/d for 5 days, followed by $10 \mathrm{mg} / \mathrm{d}$ for 5 days) or usual care. Patients receiving dexamethasone had more ventilator-free days (6.6 vs $4.0 ; P=.04)$, although the 28 day mortality was not significantly different (56\% vs $62 \% ; P=.83) .{ }^{38}$ Potential reasons for differences between RECOVERY, CoDEX, and other studies are very possibly related to dosage of steroids, the timing of the administration (early administration may decrease the ability to impair clearance of virus), and severity of illness (increased benefit in those requiring more ventilatory support). ${ }^{41} \mathrm{~A}$ reevaluation of the use of steroids in other viral pneumonias may be warranted, with careful attention to trial design (dose, timing, and severity of illness); this would likely impact the body of evidence for steroids in ARDS.

\section{Inhaled Pulmonary Vasodilators}

Vasculopathy in ARDS can contribute to worsening ventilation-perfusion matching and increased dead space ventilation. On a microvascular level, both thromboembolic and endothelial cell injury can result in a decrease in pulmonary blood flow, and hypoxic vasoconstriction also occurs. ${ }^{42}$ Together, these phenomena lead to a ventilatoryperfusion mismatch and increased dead space ventilation. An increased dead space fraction is associated with higher mortality in patients with ARDS. ${ }^{43}$ Inhaled pulmonary vasodilators such as nitric oxide and prostacyclins are sometimes used as therapeutic agents in ARDS with the goal of improving oxygenation and decreasing dead space.

Inhaled nitric oxide (iNO) diffuses through the alveoli into pulmonary vascular smooth muscle cells where it causes smooth muscle relaxation via an increase in cyclic GMP. ${ }^{44}$ Vasodilation results in improved perfusion to ventilated areas of lung, and thus better ventilation-perfusion matching. In a well-designed, multicenter, randomized, blinded, placebo-controlled study of iNO (5 ppm) in 385 patients with ARDS $(\mathrm{P} / \mathrm{F} \leq 250)$, oxygenation did indeed improve significantly with the use of iNO compared with placebo. Despite this finding, iNO had no impact on either the primary end point of days alive and off assisted ventilation, or the secondary end point of mortality. ${ }^{45}$ A subsequent meta-analysis of iNO treatment for ARDS has similarly demonstrated that iNO is associated with improvements in oxygenation, but no significant change in mortality, duration of mechanical ventilation, or ICU length of stay. Improvements in oxygenation also tend to be small and transient, and iNO is associated with an increased incidence of renal failure. ${ }^{46}$

Prostacyclins act on G-protein-coupled receptors in the pulmonary vasculature to increase cyclic adenosine monophosphate, and ultimately vascular smooth muscle relaxation. ${ }^{47}$ Like iNO, inhaled prostacyclins have also been shown to improve oxygenation. However, no trials have yet demonstrated an effect on mortality in ARDS ${ }^{48-51}$

Despite the paucity of evidence supporting their use, inhaled pulmonary vasodilators are used in a small but significant number of patients with ARDS. Their use was reported in $13 \%$ of patients with severe ARDS in a large global cohort. ${ }^{2}$ Although they may improve right heart function, decrease ventilation-perfusion mismatch, and improve oxygenation, ${ }^{52-54}$ pulmonary vasodilators have yet to demonstrate any impact on mortality or other patient-centered outcomes, so their routine use in ARDS cannot be recommended. However, they may be of some usefulness in patients with concurrent right ventricular failure, as a temporizing measure for patients requiring transportation, or as a short-term rescue therapy for patients with refractory 
hypoxia before the initiation of extracorporeal support. Their utility in other situations requires further research.

\section{Investigational Therapies: Vitamin C}

In animal models of sepsis and lung injury, vitamin $C$ has been shown to act on a number of physiologic derangements present in ARDS, including attenuating inflammation, improving epithelial-endothelial function, speeding resolution of pulmonary edema fluid, and decreasing coagulopathy. ${ }^{55-58}$ Intravenous vitamin $C$ has also been evaluated in clinical trials of the critically ill. Administration of high-dose vitamin $\mathrm{C}$ at $66 \mathrm{mg} / \mathrm{kg} / \mathrm{h}$ in burn patients has been found to decrease the need for intravenous fluid resuscitation, and potentially decrease respiratory dysfunction. ${ }^{59}$ In critically ill patients with sepsis, a phase I study of vitamin $C$ versus placebo demonstrated that high-dose infused vitamin $\mathrm{C}$ was safe, and potentially beneficial as reflected in an improved modified Sequential Organ Failure Assessment (mSOFA) scores, a decrease in inflammatory, and a nonstatistically significant decrease in ICU length of stay. ${ }^{60}$ Because of these preliminary findings, a multicenter, randomized, double-blind, placebo-controlled trial of 167 patients was conducted to examine the effects of highdose intravenous vitamin C (50 mg/kg every 6 hours for 96 hours) on the primary outcome measures of mSOFA score and plasma markers of inflammation and vascular injury in patients with ARDS and sepsis. Although the mSOFA scores, biomarkers of inflammation, and vascular injury were not significantly decreased, the secondary outcomes of 28-day mortality, ICU-free days, and hospital-free days did favor the use of vitamin $C$ (Table 4). ${ }^{61}$ One criticism of the trial was that the mSOFA scores of patients who died or were discharged before the conclusion of the 96-hour study period were excluded from the analysis. In a post hoc analysis incorporating maximum mSOFA scores (20) for patients who were deceased, and minimum scores (0) for those who were discharged alive, a statistically significant improvement of mSOFA score at 96 hours was seen in patients receiving vitamin C. ${ }^{62}$ These findings are exploratory and require confirmation in larger randomized controlled trials.

\section{Beta-Agonists}

The end result of inflammation, alveolar epithelial-capillary endothelial dysfunction, and dysfunctional fluid clearance is flooding of the alveolar spaces with fluid and pulmonary edema formation. Beta-agonists stimulate alveolar fluid clearance and have been explored as therapeutic agents for ARDS. Their mechanism of action may occur through vectorial transport of sodium from the alveolar space via apical amiloridesensitive $\mathrm{Na}$ channels on alveolar type II cells, and then egress via basolateral $\mathrm{Na}$,

\begin{tabular}{|c|c|c|}
\hline \multicolumn{3}{|l|}{$\begin{array}{l}\text { Table } 4 \\
\text { Key end points in CITRUS-ALI trial }\end{array}$} \\
\hline Variable & $\begin{array}{l}\text { Vitamin } \\
\text { C }\end{array}$ & Placebo \\
\hline Change in mSOFA at $96 \mathrm{~h}$, mean $^{\mathrm{a}}$ & 3 & 3.5 \\
\hline All-cause mortality to day $28, \%^{\mathrm{b}}$ & $29.8 \%$ & $46.3 \%$ \\
\hline Ventilator-free days to day 28, median $^{\mathrm{b}}$ & 13.1 & 10.6 \\
\hline ICU-free days to day 28, median $^{b}$ & 10.7 & 7.7 \\
\hline Hospital-free days to day 28, median $^{\text {b }}$ & 22.6 & 15.5 \\
\hline
\end{tabular}

a Primary end point.

b Secondary end point. 
K-ATPase pumps. ${ }^{63}$ Additionally, beta-agonists may decrease lung vascular permeability. ${ }^{64}$

Despite their theoretic advantages, in a multicenter, randomized controlled trial comparing aerosolized albuterol with placebo in 282 patients with ARDS, ${ }^{65}$ patients receiving albuterol had significantly more ICU days but no significant difference in mortality or days of mechanical ventilation. A subsequent randomized controlled trial of 236 patients assessing the effects of intravenous salbutamol on patients with ARDS found that treatment was poorly tolerated and was associated with increased mortality (34\% vs 23\%; relative risk, 1.47; 95\% confidence interval, $1.03-2.08) .{ }^{66}$ Routine treatment of established ARDS with beta-agonists should thus be avoided, as it may be associated with harm. However, the combination of beta-agonists with corticosteroids, may have a role in preventing the progression of at-risk patients to ARDS. ${ }^{67}$ In a pilot study, 61 patients at risk of developing ARDS based on the presence of at least 1 risk factor and a Lung Injury Prevention Score of 4 or higher were randomized to either placebo or inhaled budesonide and formoterol. Those randomized to the intervention demonstrated improved oxygenation based on the S/F ratio. Additional trials are ongoing, including the Arrest RESpiraTory Failure from PNEUMONIA (ARREST) trial, which examines whether inhaled beta-agonists and corticosteroids can prevent acute respiratory failure in patients with hypoxemia and pneumonia (NCT04193878).

\section{Statins}

By inhibiting the conversion of 3-hydroxy-3-methylglutaryl-coenzyme A to L-mevalonate, statins not only inhibit cholesterol synthesis in the liver, but also the production of multiple downstream signaling molecules, which may be the etiology of their antiinflammatory effects. ${ }^{68}$ Statins decrease inflammation and lung injury in murine and human models, ${ }^{69,70}$ suggesting a possible role for their use in ARDS. However, both rosuvastatin and simvastatin have been evaluated in multicenter, double-blinded, randomized controlled trials, and neither drug has been shown to decrease mortality or days of mechanical ventilation. ${ }^{71,72}$ A secondary analysis of the simvastatin study did, however, reveal a differential response to statins in patients with hypoinflammatory and hyperinflammatory subphenotypes, suggesting its possible value for subsets of patients with a hyperinflammatory ARDS phenotype. ${ }^{73}$ Prospective confirmation of these findings is needed in a randomized controlled trial.

\section{Mesenchymal Stromal Cells}

Preclinical studies suggest that human mesenchymal stromal cells (MSCs) may have the ability to attenuate inflammation, enhance resolution of lung injury, and facilitate bacterial clearance, and thus hold promise for the treatment of ARDS. MSCs have been found to improve mortality in murine lung injury models, and in ex vivo human lungs. ${ }^{74}$ On the basis of these findings, preliminary trials assessing the use of MSCs in patients with moderate-to-severe ARDS have been performed, which have demonstrated that that MSCs are safe and well-tolerated. ${ }^{74-76}$ Additionally, an initial report of results from the MUST-ARDS trial, which assessed the use of bone marrow-derived MSCs in patients with moderate to severe ARDS in 30 patients, suggested that the use of MSCs may be associated with decreased mortality, as well as increased ventilator-free days and ICU-free days. However, the primary end point of this study was safety; it was not powered to assess these secondary end points. Although this initial report is promising, further research is needed to determine the efficacy of MSCs, and multiple clinical trials are ongoing (NCT02444455, NCT03608592, NCT03042143, NCT04367077). ${ }^{77}$ 


\section{Granulocyte-Macrophage Colony Stimulating Factor}

Granulocyte-macrophage colony stimulating factor (GM-CSF) plays important roles in surfactant clearance, pulmonary innate immunity, and the growth and survival of alveolar epithelial cells. In animal models, it has been found to prevent hyperoxia-induced lung injury, possibly by limiting epithelial cell injury. ${ }^{78}$ Higher concentrations of GMCSF in the bronchoalveolar lavage fluid from patients with ARDS may also be associated with increased survival. ${ }^{79}$ Its use as a therapeutic remains unclear at this time. In a randomized, double-blind, placebo-controlled trial of intravenous GM-CSF in 130 patients with ARDS, there were trends toward lower mortality rates and increased organ failure-free days, but these differences did not achieve statistical significance. ${ }^{80} \mathrm{~A}$ small study of inhalational GM-CSF suggested that its use may improve oxygenation and severity of illness ${ }^{81}$; these findings are being further assessed in a multicenter trial (NCT02595060).

\section{Challenges and Future Directions}

The potential reasons why no single pharmacologic treatment has definitively been found to be beneficial in ARDS are manifold. The pathogenesis of ARDS is complex, and involves multiple mechanisms of injury, possibly rendering interventions targeted to single mediators ineffective. There is also substantial heterogeneity in this syndrome-a multitude of etiologies exist, as does a wide spectrum of severity. Variability exists even in the management of ARDS,${ }^{18}$ creating challenges in the evaluation of any single therapy.

In light of these issues, there has been growing interest in the personalization of care in ARDS. A number of strategies have been used to derive homogenous subgroups in ARDS, including categorization based on physiology, etiology, biomarkers, or gene expression. ${ }^{82}$ Identifying distinct subsets may increase the likelihood of either response or adverse outcome associated with specific interventions, and as such provide an opportunity for improving patient selection for clinical trials on therapeutics for ARDS. ${ }^{83,84}$ As an example, subphenotypes of ARDS with variable levels of inflammation have been identified by using latent class analysis to examine clinical and biological data. ${ }^{85}$ These subphenotypes have exhibited divergent clinical outcomes and differential response to specific supportive and pharmacologic therapies. ${ }^{73,86}$ Although targeting ARDS therapies to subphenotypes holds promise, another challenge lies in the capability of rapidly identifying such subphenotypes at the bedside. Methods for doing so must first be developed before personalized approaches can be assessed in a meaningful manner.

Additionally, the COVID-19 pandemic has spawned numerous clinical trials, including those involving steroids and immunomodulatory therapies such as IL-1 inhibitors, anti-IL-6 receptor monoclonal antibodies, and interferons. To date, aside from dexamethasone, no agent has yet demonstrated a clear benefit in COVID-19related ARDS. However, many trials are still ongoing and their impact on ARDS care remains to be seen.

\section{SUMMARY}

No pharmacologic interventions have yet demonstrated a clear mortality benefit in ARDS, although some have been associated with improvement in surrogate end points. There is a growing body of evidence suggesting that corticosteroids may be beneficial. Additionally, a number of investigational therapies such as vitamin $\mathrm{C}$, mesenchymal stem cells, and GM-CSF may be promising, but further research is needed. 


\section{CLINICS CARE POINTS}

- The cornerstone of care for ARDS remains lung protective ventilation, because no definitive pharmacologic therapies have yet been found.

- Currently, the most promising pharmacologic therapy for ARDS is corticosteroid. Timing of administration, however, matters because the benefit has only been seen when initiated in early ARDS. There is no benefit to starting systemic steroid therapy at 7 or more days after the onset of ARDS.

- Although there is no impact on survival, neuromuscular blockade can be of usefulness in carefully selected patients with moderate to severe ARDS.

- We cannot recommend any other pharmacologic interventions at this time given the lack of evidence, although investigations are ongoing for high-dose vitamin C, MSCs, and other potential therapies.

\section{DISCLOSURE}

N. Qadir reports no significant conflicts of interest; S.Y. Chang was an advisor for a COVID trial to PureTech Pharmaceuticals in 2020; and was a speaker for La Jolla Pharmaceuticals in 2018.

\section{REFERENCES}

1. Ashbaugh DG, Bigelow DB, Petty TL, et al. Acute respiratory distress in adults. Lancet 1967;2:319-23.

2. Bellani G, Laffey JG, Pham T, et al. Epidemiology, patterns of care, and mortality for patients with acute respiratory distress syndrome in intensive care units in 50 countries. J Am Med Assoc 2016;315:788-800.

3. Dreyfuss D, Soler P, Basset G, et al. High inflation pressure pulmonary edema. Respective effects of high airway pressure, high tidal volume, and positive end-expiratory pressure. Am Rev Respir Dis 1988;137:1159-64.

4. Matthay MA, Ware LB, Zimmerman GA. The acute respiratory distress syndrome. J Clin Invest 2012;122:2731-40.

5. Acute Respiratory Distress Syndrome N, Brower RG, Matthay MA, et al. Ventilation with lower tidal volumes as compared with traditional tidal volumes for acute lung injury and the acute respiratory distress syndrome. N Engl J Med 2000;342:1301-8.

6. Meade MO, Cook DJ, Guyatt GH, et al. Ventilation strategy using low tidal volumes, recruitment maneuvers, and high positive end-expiratory pressure for acute lung injury and acute respiratory distress syndrome: a randomized controlled trial. J Am Med Assoc 2008;299:637-45.

7. Kress JP, Pohlman AS, O'Connor MF, et al. Daily interruption of sedative infusions in critically ill patients undergoing mechanical ventilation. N Engl J Med 2000;342: $1471-7$.

8. Hansen-Flaschen J, Cowen J, Raps EC. Neuromuscular blockade in the intensive care unit. More than we bargained for. Am Rev Respir Dis 1993;147:234-6.

9. Forel JM, Roch A, Marin V, et al. Neuromuscular blocking agents decrease inflammatory response in patients presenting with acute respiratory distress syndrome. Crit Care Med 2006;34:2749-57.

10. Fanelli V, Morita Y, Cappello P, et al. Neuromuscular blocking agent cisatracurium attenuates lung injury by inhibition of nicotinic acetylcholine receptor-alpha1. Anesthesiology 2016;124:132-40. 
11. National Heart L, Blood Institute PCTN, Moss M, et al. Early neuromuscular blockade in the acute respiratory distress syndrome. N Engl J Med 2019;380: 1997-2008.

12. Sottile PD, Kiser TH, Burnham EL, et al. An observational study of the efficacy of cisatracurium compared with vecuronium in patients with or at risk for acute respiratory distress syndrome. Am J Respir Crit Care Med 2018;197:897-904.

13. Papazian L, Forel JM, Gacouin A, et al. Neuromuscular blockers in early acute respiratory distress syndrome. N Engl J Med 2010;363:1107-16.

14. Dodia NN, Richert ME, Deitchman AR, et al. A survey of academic intensivists' Use of neuromuscular blockade in subjects with ARDS. Respir Care 2020;65: 362-8.

15. Girard TD, Kress JP, Fuchs BD, et al. Efficacy and safety of a paired sedation and ventilator weaning protocol for mechanically ventilated patients in intensive care (Awakening and Breathing Controlled trial): a randomised controlled trial. Lancet 2008;371:126-34.

16. Ware LB, Matthay MA. The acute respiratory distress syndrome. N Engl J Med 2000;342:1334-49.

17. Barnes PJ. How corticosteroids control inflammation: quintiles prize lecture 2005. Br J Pharmacol 2006;148:245-54.

18. Qadir N, Bartz RR, Cooter ML, et al. Variation in Early Management Practices in Moderate-to-Severe Acute Respiratory Distress Syndrome in the United States. Chest 2021. https://doi.org/10.1016/j.chest.2021.05.047.

19. Bernard GR, Luce JM, Sprung CL, et al. High-dose corticosteroids in patients with the adult respiratory distress syndrome. N Engl J Med 1987;317:1565-70.

20. Meduri GU, Headley AS, Golden E, et al. Effect of prolonged methylprednisolone therapy in unresolving acute respiratory distress syndrome: a randomized controlled trial. J Am Med Assoc 1998;280:159-65.

21. Meduri GU, Golden E, Freire AX, et al. Methylprednisolone infusion in early severe ARDS: results of a randomized controlled trial. Chest 2007;131:954-63.

22. Steinberg KP, Hudson LD, Goodman RB, et al. Efficacy and safety of corticosteroids for persistent acute respiratory distress syndrome. N Engl J Med 2006;354: 1671-84.

23. Peter JV, John P, Graham PL, et al. Corticosteroids in the prevention and treatment of acute respiratory distress syndrome (ARDS) in adults: meta-analysis. BMJ 2008;336:1006-9.

24. Lewis SR, Pritchard MW, Thomas CM, et al. Pharmacological agents for adults with acute respiratory distress syndrome. Cochrane Database Syst Rev 2019;7: Cd004477.

25. Meduri GU, Bridges L, Shih MC, et al. Prolonged glucocorticoid treatment is associated with improved ARDS outcomes: analysis of individual patients' data from four randomized trials and trial-level meta-analysis of the updated literature. Intensive Care Med 2016;42:829-40.

26. Villar J, Ferrando C, Martinez D, et al. Dexamethasone treatment for the acute respiratory distress syndrome: a multicentre, randomised controlled trial. Lancet Respir Med 2020.

27. Confalonieri M, Urbino R, Potena A, et al. Hydrocortisone infusion for severe community- acquired pneumonia: a preliminary randomized study. Am J Respir Crit Care Med 2005;171:242-8.

28. Fernandez-Serrano S, Dorca J, Garcia-Vidal C, et al. Effect of corticosteroids on the clinical course of community-acquired pneumonia: a randomized controlled trial. Crit Care 2011;15:R96. 
29. Mikami K, Suzuki M, Kitagawa H, et al. Efficacy of corticosteroids in the treatment of community-acquired pneumonia requiring hospitalization. Lung 2007;185: 249-55.

30. Meijvis SC, Hardeman $\mathrm{H}$, Remmelts $\mathrm{HH}$, et al. Dexamethasone and length of hospital stay in patients with community-acquired pneumonia: a randomised, double-blind, placebo-controlled trial. Lancet 2011;377:2023-30.

31. Torres A, Sibila O, Ferrer M, et al. Effect of corticosteroids on treatment failure among hospitalized patients with severe community-acquired pneumonia and high inflammatory response: a randomized clinical trial. J Am Med Assoc 2015; 313:677-86.

32. Siemieniuk RA, Meade MO, Alonso-Coello P, et al. Corticosteroid therapy for patients hospitalized with community-acquired pneumonia: a systematic review and meta-analysis. Ann Intern Med 2015;163:519-28.

33. Wan YD, Sun TW, Liu ZQ, et al. Efficacy and safety of corticosteroids for community-acquired pneumonia: a systematic review and meta-analysis. Chest 2016;149:209-19.

34. Lansbury LE, Rodrigo C, Leonardi-Bee J, et al. Corticosteroids as adjunctive therapy in the treatment of influenza: an updated Cochrane systematic review and meta- analysis. Crit Care Med 2020;48:e98-106.

35. Lee N, Allen Chan KC, Hui DS, et al. Effects of early corticosteroid treatment on plasma SARS- associated Coronavirus RNA concentrations in adult patients. J Clin Virol 2004;31:304-9.

36. Arabi YM, Mandourah Y, Al-Hameed F, et al. Corticosteroid therapy for critically ill patients with Middle East respiratory syndrome. Am J Respir Crit Care Med 2018; 197:757-67.

37. Liu J, Zhang S, Dong X, et al. Corticosteroid treatment in severe COVID-19 patients with acute respiratory distress syndrome. J Clin Invest 2020;130:6417-28.

38. Tomazini BM, Maia IS, Cavalcanti AB, et al. Effect of dexamethasone on days alive and ventilator-free in patients with moderate or severe acute respiratory distress syndrome and COVID- 19: the CoDEX randomized clinical trial. J Am Med Assoc 2020;324:1307-16.

39. Sterne JAC, Murthy S, Diaz JV, et al. Association between administration of systemic corticosteroids and mortality among critically ill patients with COVID-19: a meta-analysis. J Am Med Assoc 2020;324:1330-41.

40. Horby P, Lim WS, Emberson JR, et al. Dexamethasone in hospitalized patients with Covid-19 - preliminary report. N Engl J Med 2020.

41. Matthay MA, Wick KD. Corticosteroids, COVID-19 pneumonia, and acute respiratory distress syndrome. J Clin Invest 2020;130:6218-21.

42. Tomashefski JF Jr, Davies P, Boggis C, et al. The pulmonary vascular lesions of the adult respiratory distress syndrome. Am J Pathol 1983;112:112-26.

43. Nuckton TJ, Alonso JA, Kallet RH, et al. Pulmonary dead-space fraction as a risk factor for death in the acute respiratory distress syndrome. N Engl J Med 2002; 346:1281-6.

44. Yu B, Ichinose F, Bloch DB, et al. Inhaled nitric oxide. Br J Pharmacol 2019;176: 246-55.

45. Taylor RW, Zimmerman JL, Dellinger RP, et al. Low-dose inhaled nitric oxide in patients with acute lung injury: a randomized controlled trial. J Am Med Assoc 2004; 291:1603-9.

46. Gebistorf F, Karam $O$, Wetterslev J, et al. Inhaled nitric oxide for acute respiratory distress syndrome (ARDS) in children and adults. Cochrane Database Syst Rev 2016; CD002787. 
47. Del Pozo R, Hernandez Gonzalez I, Escribano-Subias P. The prostacyclin pathway in pulmonary arterial hypertension: a clinical review. Expert Rev Respir Med 2017;11:491-503.

48. Afshari A, Bastholm Bille A, Allingstrup M. Aerosolized prostacyclins for acute respiratory distress syndrome (ARDS). Cochrane Database Syst Rev 2017;7: CD007733.

49. Dahlem P, van Aalderen WM, de Neef M, et al. Randomized controlled trial of aerosolized prostacyclin therapy in children with acute lung injury. Crit Care Med 2004;32:1055-60.

50. Walmrath D, Schneider T, Schermuly R, et al. Direct comparison of inhaled nitric oxide and aerosolized prostacyclin in acute respiratory distress syndrome. Am J Respir Crit Care Med 1996;153:991-6.

51. Fuller BM, Mohr NM, Skrupky L, et al. The use of inhaled prostaglandins in patients with ARDS: a systematic review and meta-analysis. Chest 2015;147: 1510-22.

52. Hill NS, Preston IR, Roberts KE. Inhaled therapies for pulmonary hypertension. Respir Care 2015;60:794-802, discussion -5.

53. Siobal M. Aerosolized prostacyclins. Respir Care 2004;49:640-52.

54. Hsu CW, Lee DL, Lin SL, et al. The initial response to inhaled nitric oxide treatment for intensive care unit patients with acute respiratory distress syndrome. Respiration 2008;75:288-95.

55. Mohammed BM, Fisher BJ, Kraskauskas D, et al. Vitamin C: a novel regulator of neutrophil extracellular trap formation. Nutrients 2013;5:3131-51.

56. Fisher BJ, Seropian IM, Kraskauskas D, et al. Ascorbic acid attenuates lipopolysaccharide-induced acute lung injury. Crit Care Med 2011;39:1454-60.

57. Fisher BJ, Kraskauskas D, Martin EJ, et al. Attenuation of sepsis-induced organ injury in mice by vitamin C. JPEN J Parenter Enteral Nutr 2014;38:825-39.

58. Fisher BJ, Kraskauskas D, Martin EJ, et al. Mechanisms of attenuation of abdominal sepsis induced acute lung injury by ascorbic acid. Am J Physiol Lung Cell Mol Physiol 2012;303:L20-32.

59. Tanaka H, Matsuda T, Miyagantani $Y$, et al. Reduction of resuscitation fluid volumes in severely burned patients using ascorbic acid administration: a randomized, prospective study. Arch Surg 2000;135:326-31.

60. Fowler AA 3rd, Syed AA, Knowlson S, et al. Phase I safety trial of intravenous ascorbic acid in patients with severe sepsis. J TransI Med 2014;12:32.

61. Fowler AA 3rd, Truwit JD, Hite RD, et al. Effect of vitamin C infusion on organ failure and biomarkers of inflammation and vascular injury in patients with sepsis and severe acute respiratory failure: the CITRIS-ALI randomized clinical trial. J Am Med Assoc 2019;322:1261-70.

62. Fowler AA 3rd, Fisher BJ, Kashiouris MG. Vitamin C for sepsis and acute respiratory failure- reply. J Am Med Assoc 2020;323:792-3.

63. Groshaus HE, Manocha S, Walley KR, et al. Mechanisms of beta-receptor stimulation- induced improvement of acute lung injury and pulmonary edema. Crit Care 2004;8:234-42.

64. Basran GS, Hardy JG, Woo SP, et al. Beta-2-adrenoceptor agonists as inhibitors of lung vascular permeability to radiolabelled transferrin in the adult respiratory distress syndrome in man. Eur J Nucl Med 1986;12:381-4.

65. Matthay MA, Brower RG, Carson S, et al. Randomized, placebo-controlled clinical trial of an aerosolized $\beta_{2}$-agonist for treatment of acute lung injury. Am J Respir Crit Care Med 2011;184:561-8. 
66. Gao Smith F, Perkins GD, Gates S, et al. Effect of intravenous $\beta$-2 agonist treatment on clinical outcomes in acute respiratory distress syndrome (Balti-2): a multicentre, randomised controlled trial. Lancet 2012;379:229-35.

67. Festic E, Carr GE, Cartin-Ceba R, et al. Randomized clinical trial of a combination of an inhaled corticosteroid and beta agonist in patients at risk of developing the acute respiratory distress syndrome. Crit Care Med 2017;45:798-805.

68. Oesterle A, Laufs U, Liao JK. Pleiotropic effects of statins on the cardiovascular system. Circ Res 2017;120:229-43.

69. Jacobson JR, Barnard JW, Grigoryev DN, et al. Simvastatin attenuates vascular leak and inflammation in murine inflammatory lung injury. Am J Physiol Lung Cell Mol Physiol 2005;288:L1026-32.

70. Shyamsundar M, McKeown ST, O'Kane CM, et al. Simvastatin decreases lipopolysaccharide- induced pulmonary inflammation in healthy volunteers. Am J Respir Crit Care Med 2009;179:1107-14.

71. Truwit JD, Bernard GR, Steingrub J, et al. Rosuvastatin for sepsis-associated acute respiratory distress syndrome. N Engl J Med 2014;370:2191-200.

72. McAuley DF, Laffey JG, O'Kane CM, et al. Simvastatin in the acute respiratory distress syndrome. N Engl J Med 2014;371:1695-703.

73. Calfee CS, Delucchi KL, Sinha P, et al. Acute respiratory distress syndrome subphenotypes and differential response to simvastatin: secondary analysis of a randomised controlled trial. Lancet Respir Med 2018;6:691-8.

74. Matthay MA. Therapeutic potential of mesenchymal stromal cells for acute respiratory distress syndrome. Ann Am Thorac Soc 2015;12(Suppl 1):S54-7.

75. Wilson JG, Liu KD, Zhuo H, et al. Mesenchymal stem (stromal) cells for treatment of ARDS: a phase 1 clinical trial. Lancet Respir Med 2015;3:24-32.

76. Yip HK, Fang WF, Li YC, et al. Human umbilical cord-derived mesenchymal stem cells for acute respiratory distress syndrome. Crit Care Med 2020;48:e391-9.

77. Jacono F, Bannard-Smith J, Brealey D, et al. Primary analysis of a phase 1/2 study to assess MultiStem ${ }^{\circledR}$ cell therapy, a regenerative advanced therapy medicinal product (ATMP), in acute respiratory distress syndrome (MUST-ARDS). Am J Respir Crit Care Med 2020;201:A7353.

78. Paine R 3rd, Wilcoxen SE, Morris SB, et al. Transgenic overexpression of granulocyte macrophage-colony stimulating factor in the lung prevents hyperoxic lung injury. Am J Pathol 2003;163:2397-406.

79. Matute-Bello G, Liles WC, Radella F 2nd, et al. Modulation of neutrophil apoptosis by granulocyte colony-stimulating factor and granulocyte/macrophage colonystimulating factor during the course of acute respiratory distress syndrome. Crit Care Med 2000;28:1-7.

80. Paine R 3rd, Standiford TJ, Dechert RE, et al. A randomized trial of recombinant human granulocyte-macrophage colony stimulating factor for patients with acute lung injury. Crit Care Med 2012;40:90-7.

81. Herold S, Hoegner K, Vadasz I, et al. Inhaled granulocyte/macrophage colonystimulating factor as treatment of pneumonia-associated acute respiratory distress syndrome. Am J Respir Crit Care Med 2014;189:609-11.

82. Sinha $P$, Calfee CS. Phenotypes in acute respiratory distress syndrome: moving towards precision medicine. Curr Opin Crit Care 2019;25:12-20.

83. Matthay MA, Arabi YM, Siegel ER, et al. Phenotypes and personalized medicine in the acute respiratory distress syndrome. Intensive Care Med 2020;46:2136-52.

84. Ware LB, Matthay MA, Mebazaa A. Designing an ARDS trial for 2020 and beyond: focus on enrichment strategies. Intensive Care Med 2020;46:2153-6. 
85. Sinha P, Churpek MM, Calfee CS. Machine learning classifier models can identify acute respiratory distress syndrome phenotypes using readily available clinical data. Am J Respir Crit Care Med 2020;202:996-1004.

86. Famous KR, Delucchi K, Ware LB, et al. Acute respiratory distress syndrome subphenotypes respond differently to randomized fluid management strategy. Am J Respir Crit Care Med 2017;195:331-8.

87. Spragg RG, Taut FJ, Lewis JF, et al. Recombinant surfactant protein C-based surfactant for patients with severe direct lung injury. Am J Respir Crit Care Med 2011;183:1055-61.

88. Willson DF, Truwit JD, Conaway MR, et al. The adult calfactant in acute respiratory distress syndrome trial. Chest 2015;148:356-64.

89. Ranieri VM, Pettila V, Karvonen MK, et al. Effect of intravenous interferon beta-1a on death and days free from mechanical ventilation among patients with moderate to severe acute respiratory distress syndrome: a randomized clinical trial. J Am Med Assoc 2020. 